\title{
Critical methodologies: early childhood research studies in Norway
}

Jeanette Rhedding-Jones

Oslo and Akershus University College of applied sciences

Agnes W. Bjelkerud agnes.bjelkerud@hihm.no

Hedmark University College

Katrine Giæver katrine.giaver@hioa.no

Oslo and Akershus University College of applied sciences

Eline Grelland Røkholt eline.grelland.rokholt@ahus.no

Akershus University Hospital

Ingeborg S. Holten ingeborg.holten@hioa.no

Oslo and Akershus University College of applied sciences

Tove Lafton tove.lafton@hioa.no

Oslo and Akershus University College of applied sciences

Anna R. Moxnes anna.moxnes@hbv.no

Buskerud and Vestfold University College

Liv Alice Pope liv.alice.pope@bgr.oslo.kommune.no

Oslo Kommunes barnehager, Grorud Bydel

Keywords: Research methodologies, critical, early childhood, poststructural, phenomenology, difference, postpositivist

This chapter exemplifies seven projects and their related research methodologies. It does so to consider how to construct critical research studies without replicating someone else's research methodology and without setting up models. In other words, this is about how to do a project and how to write about it theoretically and conceptually: by letting the methodologies emerge as the project is undertaken. Each project began with a researcher deciding which critical issue (Yelland, 2005) would be investigated and explored, in practice and in theory. The researchers were all attempting their first 'real research,' at the Masters level, which meant each had to eventually produce a single-authored piece of writing of about 100 pages, plus a comprehensive reference list and relevant appendices. Each dissertation written about in this chapter was rated as an excellent dissertation, by both its external examiner and its internal examiner. The researchers/graduate students were, in alphabetical order, Agnes, Anna, Eline, Ingeborg, Katrine, Liv and Tove. They are named as co-writers of this chapter. Jeanette was the veileder. This is a Norwegian term meaning mentor and supervisor, for a project that takes a year or two of full-time work after twelve months of coursework at Masters level; double that if the degree is part-time.

All of the dissertations, with their embedded theses and their methodological practices, were written in Norwegian, with a summary in English. It is from the English-language summary that this chapter 
develops, and from Jeanette's readings of both languages. The coursework each researcher had previously studied included courses in research methodology (forskningsmetodologi), in theories of scientific knowledge (vitenskapsteori), in critical issues and diversity (kritisk tema og magnfold), and in children, childhood and children's centres (barn, barndom og barnehager). Barnehage is a Norwegian term, often translated as kindergartens or preschools in English. With these as a background each researcher had her own ideas about what mattered. Yes, all were women, and all completed their projects and the related academic writing quite recently, as can be seen from the reference list to this chapter.

Said briefly, the critical issues which informed each project were 'social competence' in children (Agnes); chaos and complexity in everyday life in children's centres (Anna); grief at the death of a young child's close family member (Eline); cultural/linguistic diversity and special education (Ingeborg); Muslims' memories of non-Muslim institutions for children (Katrine); childhood, social class and a particular suburb (Liv); and children's rights to decision-making and collaboration in children's centres (Tove). Each researcher began with her critical issue for which she hoped to do something useful; by producing the dissertation and its related practices. So each project was politically driven research, with its focus and its strategies based in critical perspectives, activism, and advocacy for children, awareness of power, possibilities from reconceptualizing, and a desire for changing practice or policy.

As methodologies (seen as strategies/practices connected to epistemology and ontology) the researchers took up the following. Agnes worked with rhizomatic approaches derived from Deleuze, resulting in postmodern split text effects and contemporary theoretical directions. Anna focused on philosophical and poststructuralist practices connected to concepts and document deconstructions. Eline produced bricolage by making feminist postructuralist readings of photographs, interviews and field notes. Ingeborg did a discursive analysis, mostly following Fairclough (2003), of selected statements about young children's language skills when their first language was not Norwegian. Katrine interviewed eleven Norwegian Muslims, and then considered the interviews from phenomenological perspectives because she did not want to critique. Liv analysed a range of textual documents from different sources, taking into account the poststructural. Tove led an action research project inspired by Mac Naughton (2001) and contemporary Norwegian action research.

These seven projects represent some possibilities in research methodologies (following Rhedding-Jones, 2003; 2005c) when there is a degree of freedom, and when the context for the projects and their dissertations is a research culture that accepts and encourages scholarship that is different, innovative and politically aimed to cause change. A Norwegian research culture like this has not come about easily. It has been built up over a number of years, with the help of colleagues and the dissertations/theses of past and present graduate students at the Masters and the Doctoral levels. (See Rhedding-Jones 2005a and 2007 for discussions of higher education pedagogy related to the development of this research culture and its related coursework and projects at Masters level.)

The next section deals with the seven projects, which we prefer to see here as a collective of innovative scholarship rather than as seven individual pieces of work. The researchers met on campus in colloquia groups, and also off campus at Jeanette's home, whilst they were engaged in the projects and the related academic writing. In now presenting the projects individually we hope to show how they were developed methodologically, and how their critical issues connected to the ways the research was done. We let each researcher speak through the English-language summary of her dissertation, but we add underlining to show what we think matters most to her research methodology choices. Before each researcher introduces her methodology she describes her critical project and says something about concepts and theories. After completing the dissertation, each researcher wrote her summary in Norwegian and in English. The latter was then negotiated grammatically and in terms of vocabulary with 
Jeanette, so that the 'Norwenglish' almost but not quite disappeared. For this chapter the English has gone through another språkvask (literally a language washing).

\section{Agnes}

During the last decades 'social competence' as a concept has increased in use and acknowledgement in Norwegian pedagogy. The use of this concept has also increased in national politics related to preschools (barnehager) specifically, and also in society in general. 'Social competence' here relates to human beings' skills regarding how to engage with others, and this is measured from criteria such as empathy, self-control and abilities to speak for oneself. These skills are put forward as important for children to develop, both in relation to the here-and-now and to their future learning skills and participation in Norwegian society. Thus 'prevention' is spoken of highly. In the National Curriculum Frameworks of preschools (Kunnskapsdepartementet, 2006) it is said that barnehager (for children aged from 1-6) have an important task in making sure that children develop 'social competence' at an early age. The most used understandings of 'social competence' have been constructed through time and place, and have their connections to western psychology, 'special' pedagogy and sociology. These fields have contributed to how we understand and value children's positioning's in society, and their social acts.

The contemporary pictures of the Norwegian society are complex. Meetings influence many barnehager across cultures, languages, social and religious perspectives. At the same time the national political regulations of children's participation in barnehager, and on the related pedagogical processes, have increased. It is thus of importance to put forward the request to rethink and critically reflect upon some of the conditions under which pedagogy and children's social processes are put into effect. By offering an alternative approach to the concept of 'social competence' than the ones traditionally offered, this project attempted to put multi-perspectives into/upon the mono. This is done by introducing the following: other theoretical perspectives, other ways of doing investigations around the concept of 'social competence', and by critical reflection, taking into account the cultural constructions of the concept.

The project in these ways seeks to open up the concept of 'social competence' through different entries, such as political processes and philosophical approaches. What is critical here points strongly in the directions of political processes, both nationally and locally in barnehager. These processes work both nationally and at more local levels, through decisions taken by democratically voted-for politicians. At the same time political processes can be related to conditions in barnehager, with ongoing processes between the people who have their daily bases there. Here political processes can be exemplified by who has or is given the opportunity to influence these daily bases: in other words, who gets to be heard.

The philosophical approaches introduced in this project are derived from the work of the French philosophers Deleuze and Guattari (1988) and Deleuze (1990). By putting to work their theories of the rhizome, minor/micro politics and the nomad, this project was to look for the ongoing changes and becomings of concepts, social processes and texts. This makes this project a theoretical study, though rhizomatic analyses of published texts, lines of competence (kompetanse) and prevention (forebygging) were followed. Rhizomatic and critical readings, inspired by perspectives from Deleuze and Guattari are of control, science, pedagogical processes, movement, silence and language, as these relate to 'social competence'.

Here Agnes (Bjelkerud, 2009) can be seen to be resisting any kind of empirical project, preferring instead to work with philosophy, concepts and texts that indicate how 'competence' might be seen differently. 
What she actually analysed were selected documents from various sources, such as media, policy documents from the OECD and the Norwegian government, academic quotes and diagrams. These were juxtaposed on various pages of the dissertation, with each text extract numbered, as a kind of artylooking collage. Nothing like this had been done before, at least not in this research culture. So Agnes's project was a risky one. She actually risked failing because if her examiners had not known about the work of Deleuze and Guattari they might have thought what she was doing was nonsense. We will come back to discussing methodology a bit later, after considering some of the other projects; and we will also say why we only occasionally use the term 'methods' (for further explanation see Rhedding-Jones in Hatch, 2007: 207-222). What Agnes's dissertation does is show how a postmodern text and research practice might operate as an effect of postmodernity.

\section{Anna}

This Masters dissertation is inspired by Foucault, and his thoughts about archaeology. Through retrospectives on professional practice I retell forgotten stories and uncover silenced voices as I look at a year of my own past as a professional preschool practitioner. My thinking here is that across a day in a barnehage (children's centre) I forget, fail to see, and do not give priority to reflecting over most incidents that happened with the children. In this dissertation I have tried to use the idea of archaeology to uncover artefacts from the preschool-year 2007-2008 and to reconstruct narratives from these artefacts. My desire was to get a grip on, and reflect over, fragments from busy daily life: fragments we don't prioritize in organized reflection time. So I focus on daily situations that slip our memories, those we make silent. In these ways I attempt to reveal fragments of an 'archaeology of silence' (Foucault, 2003: 18).

I suggest that the acting pedagogue does the planning, organizing, documentation and evaluation (following Kunnskapsdepartementet, 2006, the national curriculum framework document), and that through such activities a teacher tries to organize what I call chaos. When a teacher organizes chaos it is her or his thoughts about order that shine through. This is one way a teacher maintains the normalised dichotomy of adults and children, which silence children's voices and colonize children's lives in barnehager. In this dissertation I work to construct counter discourses to organized chaos, through revealing 'silence' in more or less organized daily activities from a particular preschool-year: August 2007 to June 2008.

Chaos theory from physics and mathematics has allowed me to focus on the gap non-linearity creates, and to focus on this gap as a room or space where it is possible to discover silence. In these gaps what arises can be seen as fragments of chaos. From this chaos I focus on small moments, where the dichotomy of adults and children in some ways seems to dissolve or change.

Methodologically the research project and its academic writing were created from a range of methods. I constructed strategies inspired by my reading about archeology, to uncover artefacts that could lead back to incidents usually kept out of sight. These artefacts formed foundations for my construction of narratives. As a way of being accountable to the children involved I invited them to listen to the narratives and reflect over my performances in those narratives. The children also contributed with self-constructed narratives or stories and in this way their different voices come into the dissertation. Critical reflection and deconstructions performed together with children were strategies for revealing or deconstructing power/knowledge relations. The deconstructions uncovered discourses where I inadvertently colonized children without me wanting this to happen (in the narratives and in the meetings with children helping with the deconstructions). My hope is that this awareness develops reconceptualizing thought as a professional practice. 
My research project was thus a tying together of my attempts to find silence in narratives constructed from artefacts, silence in meetings with children and silence in children's stories. I have tried to position the dissertation within epistemological concepts from postmodernity, as can be seen by my ways of writing and of conducting the project. To weave in thoughts inspired by postcolonialism, my attention was drawn to how I as a preschool pedagogue unconsciously colonized others as part of my professional work. This dissertation highlights the fact that revealing colonizing discourses in meetings between adults and children will always be an on-going process. My work as a researcher who is also a practitioner will hopefully allow questioning regarding what might happen if teachers not only give priority to organized activities but consider what they lose by ignoring the useful possibilities of chaos.

What Anna (Moxnes, 2010) did here was look at her own professional practice in retrospect. She worked ethically to position children in ways she thought were as acceptable as possible, and put this together with her understandings of postmodernity. She did so to produce methodological strategies around artifacts, following her readings of Foucault here. Anna's external examiner was a Swedish historian with an interest in postmodernity, and in preschooling as a site for conceptualizing. Anna was lucky here. What is interesting now is how Anna's interest in chaos theory (which she discovered for herself, we had no coursework about this) drove her project methodologically.

\section{Eline}

In my work with theorising for the Master's degree and working at the same time as a professional in bereavement support with young children, I challenge understandings from developmental psychology and crisis theory about children and grief. These are understandings, which are very age-related and based on the ability to verbalise feelings and experience of loss. I believe we need to unveil other aspects to capture the diversity in how children do their expressions of grief in their daily life.

The search for a way of deconstructing usage of developmental psychology led me to work in the feminist poststructural since here what matters is how knowledge is made, who makes and decides, and what discourses are available or not. I find that the perspectives in literature on children, related to crisis and loss, are so established that we find these descriptions as something natural, forgetting that at some point in time with a specific set of knowledge and rules of research someone authored these as theories. All descriptions will imply some powers of definitions that marginalise other experiences and these descriptions are not the same as (=) what children are. Therefore I see the possibility of describing expressions and meanings differently, including complexity and ambivalence, if the author is someone of different positioning from the dominant discourse.

The search for a way of embracing complexity of lived daily life of bereaved preschool children led me to bricolage as methodology. My use of bricolage, and my collaborations with preschool teachers, can be seen a resistance to what I see as the dominating therapeutic understandings of children in grief within the field of psychology and crisis. I believe we need to understand how children choose to do (or not to do) their expressions of grief in daily life, in the context of the kindergarten with other children, with adults, or alone. I argue for the need to expand theoretical understandings of expressions of grief as doings: as events of grief happening, borrowing the concept of doings from feminist poststructural works on gender. 
The kindergartens are local settings for lived events and the kindergarten teachers must be given, or take, a position as constructors of different knowledge and ways of being with children in grief. At the same time they are inscribed in many discourses of children, such as age and stages developmental theory, speech and bodily discourse. I suggest that the kindergarten should produce its own theoretical and practical knowledge about children and grief, and voice their own local competence, instead of restricting understandings to the dominant discourse of outside expertise from the field of crisis and psychology and developmental psychology.

In order to make her statements about re-thinking young children's grief, and resisting dominant discourses and practices around professionalism here, Eline (Grelland Røkholt, 2010) uses bricolage (Kincheloe and Berry, 2004). With this she puts together a series of pictures, anonymous photos and interviews with various people, including the children who are bereaved. Selected photographs show blurred faces for anonymity. A child is depicted lighting a candle on the anniversary of a close death. The children in the barnehage are sitting together with this child and some adults. The bereaved child wears a crown. By working differently with the preschool teachers and the children and their families, Eline constructs an innovative practice with children and an innovative research methodology for her project. Here searching, understanding and describing difference and complexity were what drove the project. The methodology evolved from that.

\section{Ingeborg}

Several barnehager in contemporary Norway have a high percentage of children with two or more verbal (spoken) languages. Relatedly the terms diversity (mangfold) and multicultural (flerkulturell) have also struck the field of early childhood education. My arguments are that the terms 'diverse and multicultural preschools' should involve more than the physical placement of children with diverse ethnic and cultural backgrounds. These terminologies are loaded with complexities and hence need our critical reconsideration. In the National Curriculum Frameworks for preschools (Kunnskapsdepartementet, 2006) language is an important issue for commitment. Some of my questions concerning the matters of ethnicities and languages in early childhood education are: To what extent do children's own first languages become important within preschools? And: Why, and for whom is this important?

In this project I focus on postmodern perspectives to challenge theories and discourses regarding children in Norwegian preschools who speak two or more languages. I do so because this allows me to work with the complexities I point to here, and it gives me alternative and new ways of thinking, writing and speaking about the multi-linguistic reality in Norwegian preschools. I use Foucault's work (1994) as a basis for my understanding of discourses, power and knowledge. Throughout my fieldwork I read written documents from preschool teachers (førskolelærere) concerning language and children with 'minority' backgrounds, one vignette by Rhedding- Jones (presented in 2005b) and one quote from the National Curriculum Frameworks for Preschools. The documents from preschool teachers include an inquiry they have sent to an institution where they are asking for help with 'problems' concerning language. I am problematizing specifically the descriptions of the children in these forms, and how these relate to discourses and power. These discourses often favour one first language (ettspråklighet) as the most usual or normalized practice.

The analysis research strategies follow Fairclough`s critical discourse analysis (2003) and elements from Laclau and Mouffe's theory of discourse (2002). In the analysis I also bring in elements from 
sociocultural theory. The data analysis reveals several discourses, and I am pointing specifically to six of them. I have called these a discourse of children's lack and needs; a verbal language discourse; a monolingual discourse; a Norwegian before school discourse; a first language as given meaning discourse; and a language room discourse. A key research question concerns consequences these discourses may have for children with more than one verbal language. I suggest that recognizing dominant discourses concerning children's multilingual realities is a crucial issue for reconsidering the field of early childhood education.

Here Ingeborg (Holten, 2008) arrived at her methodology because of the kind of analysis she wished to produce at the end of the project. A strong statement about the analysis of particular discourses would be likely to influence policy and practice and hence cause change. Ingeborg therefore worked towards finding out what would be useful for the field, and what had not been said before. We had no coursework dealing with Fairclough, or Laclau and Mouffe. Ingeborg found these for herself, because of her desire for an analytic framework that would be effective for her imagined readers, namely the people thinking that monolingualism was what mattered most, and testing the children accordingly. The selection of which documents to analyse was highly political, and Ingeborg was in a position to ethically use what preschool teachers wrote, what public policy states and what was in a descriptive and internationally published vignette. Ingeborg's job at that time was that of a professional language consultant to the children's centres (barnehager).

We have so far looked at four projects and briefly considered their methodologies. Before presenting the final three, we pause to make some comments. All of this is what must be called qualitative research, because it deals with particular qualities and is more preoccupied with these than with quantities. All of the projects are also what must be called postpositivist, because they are not searching for positive results; nor are they striving for certainly about findings, or presenting researchers as experts.

Postpositivism is what has followed positivism, and into it come three major approaches to social science inquiry. These are firstly an approach focusing on meaning: as in phenomenology or semantics and the related research practice of interpreting meaning, or saying what happened. Secondly, and this followed chronologically, are approaches focusing on what is critical: critical perspectives, critical theories, critical issues emanating from Foucault, or feminism or racism etc. Here the research strategies include critical analysis, discourse analysis, document analysis, and critical readings: a key methodology is action research which aims to bring about collaborative change and collectively studies each innovation. Thirdly: and this also came about in time, after phenomenology and critical approaches first appeared, are approaches with the adjective 'post' in them, meaning 'after'. Here postmodernity allows complexity and multiplicity and juxtapositiongs to be highly apparent, in texts, in practices and in theories (Rhedding-Jones, 1995; 1996). A way of theorizing this is with poststructuralist theory, though this is not the only set of theories available. The 'post' in postcolonial could be seen as an effect of postmodernism or/and an effect of critical theory: this is an example of how categorization is thrown open to flow in many directions at once. It can also happen with methodological choices when the choices are within the postmodern.

The seven projects we exemplify here are quite often resisting categorization: the researchers sometimes make up the methodological rules for themselves, justified by following their close readings of published research, theories and philosophical concepts. Here the technique tricks are to write well, to read much and use the reading in new ways; and to focus on the development of your own profession and the ethics around doing your project. We have tried to go beyond fixed rules about how research is actually done, by reconceptualising methodology (see Rhedding-Jones and Otterstad, 2010). Hence these 
exemplified Masters' projects aimed to cut new ground, so that new growths could emerge. These growths are appearing also in innovative Doctoral scholarship from Norway's early childhood education (eg. Otterstad and Andersen, 2010; Rossholt, 2009; Sandvik, 2010).

What we have said above introduces approaches to social science inquiry, with an emphasis on the postpositivist. In naming some research strategies (within the critical these are critical analysis, discourse analysis, document analysis, and critical readings) we also named a key critical methodology: action research. What characterizes this is collaboration between participants, researcher included, as practices are researched and changed. In some academic settings however, this is not seen as research at all but rather as professional learning. Here there is a fine line between terms, and there is some snobbery about who might get a research grant. An earlier methodology is case study, or the study of a particular case or cases. In postmodernity and in critical thought you can still do a case study, but you will do it differently. The differences are between modernist paradigms, the search for 'meaning', critical perspectives and post approaches to texts and methodological strategies. Another key methodology is ethnography, which can also be shaped according to the social science inquiry approach chosen. Derived from anthropology, ethnography is research about a culture or cultures. Here the researcher must be a part of that culture, though in times past 'belonging' to a foreign culture meant some kind of long-term tourism. Indigenous people currently resist ethnographic approaches from 'others'; but children are usually in no such position to stop the research that goes on in their preschools. One of the reasons why this chapter's researchers have not 'gone out to find out' what happens with children is because we are not wanting to perpetuate power structures and practices of traditional research. Our preoccupations instead are with ethics, with developing professional practices and with making visible the discourses in operation. All of this is what makes our projects critical.

We now present the next three projects. Again, we underline where the text indicates methodological choices and practices.

\section{Katrine}

This is a phenomenological study where I looked at Norwegian Muslims' meetings with kindergartens and schools, and whether they were given equal qualities in content as non-Muslim children. A base for this study was to see if diversity of meanings and views was made visible in kindergartens and schools with children who have diverse religious backgrounds. I have interviewed eleven Muslims in a life-story perspective: children and adults. Some of them have grown up in Norway and told stories from their own childhood; some worked in kindergartens; and some told about their own children.

Four critical issues came clearly through the interviews, and they were all about activities where the informants' Muslim identity became visible in contrast to the traditional content in the kindergartens and schools. This was about the right to hide their body, to eat halal food, to approach the fast, and to celebrate holidays such as Ramadan and Eid. I have used examples from the Norwegian government's guidelines for kindergartens and schools, and from different debates in media, to reflect different discourses that Muslims in Norway deal with.

I have found a positive development through one generation, and that diversity is more visible today than 20 years ago. Still there are signs that show that in some areas the development is marginal. Whether Muslim children are met with respect and recognition relies on the competence and interest of individuals who work in kindergartens and schools. Even if the government guidelines are to some extent supposed ensure that children are not exposed to 
discrimination or bullying, this is not enough to make sure that all Muslim children receive a safe adolescence and childhood.

This project of Katrine's (Giæver, 2010) was methodologically a case: that of Muslims' early childhoods in Norway. Katrine studied this by considering the transcribed interviews of eleven people, media debates, and national governmental sources. From this consideration or analysis four critical issues emerge, as Muslims see them. Here phenomenology seemed to be the most appropriate approach to inquiry, as what is apparent and what can be interpreted mattered more than postmodern complexities and critical analyses of power. Katrine did work with a theory of power, however: namely that of Arendt (1996), which was placed briefly in contrast to quotations from Bourdieu (1996) and Foucault. Katrine worked in public policy-making for the Norwegian government. The summary to her dissertation is presented in Arabic, Norwegian and English. The project was constructed for the Muslim community in Norway and for non-Muslims also.

\section{Liv}

The dissertation and thesis come from a research project performed and written within the field of early childhood education, in the faculty of preschool pedagogy. The project set out to research how universal pedagogical theories and practices are produced and how they might function within the field of practice. My starting place was a suburb in Oslo called Groruddalen. I examined universal pedagogical theories and practices in relation to the localities of this specific place. This brought social class, place and social redistribution in to my research processes as critical issues. My dissertation describes the performed investigations, deconstructions and reconceptualisations of some global, national and local discourses and concepts, which rely on assumptions that people and places are the same and develop in the same way.

My work is influenced by philosophical ways of thinking, reading and writing. In this dissertation I use the work of philosophers Derrida (2006), Deleuze (2006), Foucault (1999) and Spivak (1999). Their works have had great impact and influence on the use of critical and deconstructive approaches to inquiry. Multiple critical and post structural theories also informed the perspectives. The texts then spread out like an essay, describing the research project. The strategies for constructing new theories are multiple and shifting; theorizing following post structural ideas, doing critical and deconstructive readings of national and regional policy documents, newspapers and published research and plaiting autobiographical and literary inserts into the academic text occasionally. This constructs a contribution for and within a diverse field of early childhood research, pedagogy and education, especially directed towards those wanting to work towards critical multicultural and socially just pedagogies. My reconceptualisations of social class, place and social redistribution are hopefully a contribution to the ongoing work of reconceptualising early childhood practitioners around the world.

As can be seen by this summary, Liv (Pope, 2009) produced a dissertation that was maybe too 'over the top'. There is a difference though, in writing about a research project for a selected audience of examiners, and writing a research grant application for funding from a national research council. Being a clever writer means we must be able to shift genre, terminology and even research strategies to whoever our readers might be. Liv's project was fuelled by her own past, as many of our projects are. Having experienced effects of social class makes this the issue to be taken up, from having known from the inside what it is like to be thus positioned. So Liv refuses to interview, photograph or video: even to describe. Instead she turns to philosophy and finds through this a means to say what she burns for. The 
methodological strategies of doing multiple readings of selected policy documents and newspapers, and 'plaiting' this together with literary inserts and autobiographical snippets, were decided on later, after Liv had done much reading. Her external examiner was a Norwegian philosopher. Liv, like Agnes, Anna, Katrine and Tove, is an experienced early childhood practitioner.

\section{Tove}

Through feminist poststructural perspectives this action research project was carried out together with a group of preschool teachers and assistants. This happened in the barnehage where I am leader of all three units on a day-to-day basis. The action research deals with the reflections and critical analysis that the members of the group themselves did as these related to their own practice. As a research group of practitioners, we have tried to challenge our own sayings and doings as these regard children's participation in early childhood education.

Feminist poststructuralism has opened up and given me opportunities to explore dichotomies such as theory/practice and researcher/participants in research. All this has taken place in a field where I have my everyday professional life, which means the field is very close to me. Seeing research as subjective and the researcher as a multiple subject I began the action research thinking it would be practitioner-oriented. My positioning, however, and the way I looked at myself as a researcher, have both changed during the period of the project. The crucial point came when I was about to turn practice and the doings of actual people into academic writing and text.

Our actions have been related, by us, to deconstructions inspired by Derrida and by Lenz-Taguchi. Additionally, the project group people's development of their own critical voices has been articulated by them in meetings about their own everyday practice. Through me as the project leader this was linked to the study of power in a Foucauldian perspective, and explained in everyday language to the practitioners who are assistants and pedagogical leaders in their respective avdelinger (units) with the children. The members of the group have themselves rethought different ways of considering what a child 'is' and can be, and how such different ideas can come into our daily practice, through videos of the everyday life in the preschool. Additionally we have looked into what children's participation means to us and what this might become in our place of work and play.

What we have found may not be unique, but our processes and practices of being in this action research group inform us (and the wider field of practice and research, I hope) regarding how we can work with our own thoughts and ideas. These are related to practice and linked to theories about barnehagepedagogikk (preschool pedagogy) and values in this particular group. As action research involves emotions that gave me the idea of developing the spirals of action research in earlier research, and making the spirals into a loop, as in a rollercoaster.

Following the above I give readers of this oppgave (dissertation) an overview of the four contextual areas I now see as important to our action research project. These are (1) the national situation of Norwegian early childhood education, (2) vitenskaps-teoretiske perspektiver (perspectives to do with social science, knowledge and epistemology), (3) different ways of seeing children, and (4) the research strategy of this action research. At the end of the dissertation I try to say what this work has trigged in me.

I have many questions I would like to investigate further. These include: What is early childhood education pedagogy in Norway and what do we practitioner/researchers want it to become? How might we usefully reflect upon practice in today's preschool? What are our thoughts about 
participation, democracy and individuality as these apply to children and to practitioners in preschools?

This project is not the only feminist poststructuralist action research project to come through the Oslo research culture at the Masters level, so Tove (Lafton, 2008) was able to build methodologically on those. She also builds her ways of doing deconstructions from her combined readings of Derrida and of Lenz Taguchi (2004). The project took place in the preschool where Tove worked every day as the leader of three units with young children. Here the practitioner group reflected on and critically analysed that they saw as relating to their own practice and the critical question of whether the children were actually decision-makers together with the adults. To have something to look at, the adults videoed themselves in their everyday work/life with the children. Tove's unique contribution to action research methodology was her development of spirals of emotions, where these were made into a loop 'as in a rollercoaster'.

As can be seen, the term 'methods' is absent from these summaries. This is a strategic choice allowing for more flexibility, less fixedness about what you must do to do a project, and more theoretical combinations of how to do research, where you are culturally located ontologically. We are saying that research cultures themselves allow for changes in how research gets done, what researchers focus on, and how a text is constructed. At the Masters level in Norway this research culture includes people who see not 'methods' but strategies and practices within methodologies. The ways you do your action research project, ethnography or case study will differ according to your approach to social science inquiry: as a phenomenologist, a critical theorist or a postmodern writer, or combinations of these. Each methodology (for a project that is a study of a case, or is action research, or is ethnographically driven) is located within phenomenology, critical perspectives or postmodern approaches and it contains research practices. These might be interviewing, photography or videoing, writing a research journal, or collecting documents. Something then has to be done with these objects, data, transcripts, materials, texts or artifacts that come from the practice of doing your research project, so that some sort of analysis, interpretation, deconstruction or critique is made, or something is obliquely pointed to by the art of the text. These are the strategies of textualizing the practices. What you have to do as a contemporary researcher, following this, is to say where you stand and why you decided to what you did as you searched and re-searched for what might make a difference.

How does all this connect to what is critical? What we are critical of is research that is not aware of where it comes from ideologically and historically, and of what power structures it perpetuates. We are thus critical of research not from the inside: that which is produced by 'experts observing and recording' events, sites and practices that are not their own. Finding out 'what happens', we would argue, is too simplistic. Similarly, coming up with a theory that explains or says 'what is' can not be counted as critical research. For methodology to be critical, all of this has to be made apparent and put into practice, by the doing of the project and the ways by which it is inscribed as texts. Constructing such a project involves reading publications about other such projects and then putting together some of their research practices with whatever it is you make up yourself. What you make up depends on what you have experienced and read about as a critical issue, for which something must be done.

\section{References}

Arendt, H. (1996/1958) Vita Activa. The Human Condition (Det virksomme liv. Chicago: University of Chicago. (Norwegian trans. C. Janns) Oslo: Pax forlag.

Bjelkerud, A. W. (2009) Kontroll, lines of flight og 'sosial kompetanse'. Rekonseptualiseringer av 'sosial kompetanse' gjennom rhizomatiske tilnærminger (Control, lines of flight and 'social 
competence': reconceptualizations of 'social competence' with rhizomatic approaches). Masters dissertation in Early Childhood Education, Oslo University College, Norway. Published as HiOmasteroppgaver $2009 \mathrm{nr} 11$.

Bourdieu, P. (1996/1994) Symbolsk makt. (Symbolic Power) Editions du Seuil 1994. (Norwegian trans. A, Prieur, 1996) Oslo: Pax forlag.

Deleuze, Gilles (1990). Post-scriptum sur les sociétés de contrôle. (English version). http://kostisvelonis.blogspot.com/2009/01/society-of-control-i.html [30.03.09].

Deleuze, G. and Guattari, F. (1988) A Thousand Plateaus: Capitalism and schizophrenia. (English trans. B. Massumi ) London: The Athlone Press. (First edition 1980 Mille Plateaux, volume 2 of Capitalisme et Schizophrénie. Paris: Les Éditions de Minuit.)

Derrida, J. (1976) Of Grammatology (English trans. G.C. Spivak) Baltimore: Johns Hopkins University Press.

Fairclough, N. (2003/2008) Analysing Discourse: Textual analysis for social research. London and New York: Routledge. (Kritisk diskursanalyse: En tekstsamling 2008, Norwegian trans. E. H. Jensen, Copenhagen, Denmark: Hans Reitzel Forlag.)

Foucault, M. (2003/1973) Galskapens historie i opplysningens tidsalder. (The History of Madness)(Norwegian trans. F. Engelstad and E. Falkum, 2003) Trondheim: Gyldendal.

Foucault, M. (1999/1971) Diskursens orden. (The Order of Things) Tiltredelsesforelesning holdt ved Collège de France 2. desember 1970. (Lectures presented originally in 1970) (Norwegian trans. E. Schaanning, 1999) Oslo: Spartacus Forlag.

Foucault, M. (1975/1994) Overvåkning og straff. Det moderne fengsels historie (The History of the Prison) (Norwegian trans. D. Østerberg). Oslo: Gyldendal Norsk Forlag.

Giæver, K. ( 2010) 'Jeg prøvde å fortelle at islam betyr fred'. En fenomenologisk studie av elleve norske muslimers møter med barnehager og skoler. ('I tried to say that Islam means peace.' A phenomenological study of eleven Norwegian Muslims' meetings with children's centres and schools) Masters dissertation in Early Childhood Education, Oslo University College, Norway. Published as HiO-masteroppgaver.

Grelland Røkholt, E. (2010) "Sorgen i barnet og barnets hverdagsliv i barnehagen" om noen barnehagers møter med barnets sorguttrykk i barnehagens hverdagsliv, sett gjennom en feministisk poststrukturalistisk inspirert dekonstruksjon av sorg hos førskolebarn (som har mistet et nært familiemedlem). (Young children's grief and everyday life in children's centres: a feminist poststructuralist deconstruction of grief where children have lost a close family member) Masters dissertation in Early Childhood Education, Oslo University College, Norway. Published as HiO-masteroppgaver.

Hatch, A. (ed.) (2007) Early Childhood Qualitative Research. New York and Milton Park: Routledge.

Holten, I. S. (2008) Barn av språket. En kritisk og teoretisk studie av diskurser i flerspråklige og spesialpedagogiske kontekster (Children of the language: a critical and theoretical study of discourses in multilingual and special education contexts). Masters dissertation in Early Childhood Education, Oslo University College, Norway. Published as HiO-masteroppgaver 2009. nr. 1.

Kincheloe, J. and Berry, K. (2004) Rigour and Complexity in Educational Research: Conceptualizing bricolage. London: Open University Press.

Kunnskapsdepartementet (2006) Rammeplan for barnehagens innhold og oppgaver (National Curriculum Frameworks for Preschools). The Ministry of Education: Oslo, Norway.

Laclau, E. and Mouffe, C. (2002) Det radikale demokrati - diskursteoriens politiske perspektiv.

Fredriksberg: Roskilde Universitetsforlag. (Norwegian translation of Laclau E. and Mouffe C., 2001, Hegemony and Socialist Strategy: Towards a Radical Democratic Politics, second edition. London: Verso.) 
Lafton, T. (2008) Aksjonsforskning og barns medvirkning med postmoderne blikk. Foucault og Derrida i barnehagen (Action research and children's rights to decision-making: Foucault and Derrida in the Children's Centre). Masters dissertation in Early Childhood Education, Oslo University College, Norway. Published as HiO-masteroppgaver 2009.

Lenz Taguchi, H. (2004) In på bara benet: en introduction till feministisk poststructuralism (Down to Bare Bones: An introduction to feminist poststructuralist theory). Stockholm, Sweden: HLS Förlag.

Mac Naughton, G. (2001) Action research. In G. Mac Naughton, S.A. Rolfe and I Siraj-Blatchford (eds) Doing early Childhood research: International perspectives on theory and practice. Buckingham Uk and Philadelphia USA: Open University Press, pp. 208-223.

Moxnes, A. R. (2010) Stillhet i kaos. Retrospekter på makt i profesjonsutøvelse (Silence in chaos: retrospectives on power in professional work in Children's Centres). Masters dissertation in Early Childhood Education, Oslo University College, Norway. Published as HiO-masteroppgaver

Otterstad, A. M. and Andersen, C. E. (2010). Å utforske sosial ulikhet som aktivister (Researching social difference as activist researchers). Barnehagefolk (Norwegian Preschool Journal), Volume 26, number 4, pp. 44-49.

Pope, L. A. (2009) Groruddalen i documenter; På vei mot locale pedagogikkER. Rekonseptualiseringer av sted, sosiale klasser og social utjevning. (Groruddalen [a suburb in Oslo] in documentations: towards local pedagogies in the plural). Masters dissertation in Early Childhood Education, Oslo University College, Norway. Published as HiO-masteroppgaver 2009 nr 10.

Rhedding-Jones, J. (1995) What do you do after you've met poststructuralism? Research possibilities regarding feminism, ethnography and literacy, Journal of Curriculum Studies, 27(5): 479-500.

Rhedding-Jones, J. (1996) Researching early schooling: poststructural practices and academic writing in an ethnography. British Journal of Sociology of Education, 17(1): 17-37.

Rhedding-Jones, J. (2003) Feminist methodologies and research for early childhood literacies. In N. Hall, J. Larson and J. Marsh (eds) Handbook of Early Childhood Literacy, London, Thousand Oaks and New Delhi: SAGE, pp. 400-410.

Rhedding-Jones, J. (2005a) Decentering Anglo-American curricular power in early childhood education: learning, culture and 'child development' in higher education coursework. Journal of Curriculum Theorizing. 21(3): 133-155.

Rhedding-Jones, J. (2005b) Questioning diversity: rethinking early childhood practices. In N.Yelland (ed.) Critical Issues in Early Childhood Education. Berkshire and New York: Open University Press.

Rhedding-Jones, J. (2005c). What is Research? Methodological practices and new approaches. Oslo Norway: Universitetsforlaget.

Rhedding-Jones, J. (2007) Who chooses what research methodology? In J. A. Hatch (ed.) Early Childhood Qualitative Research. New York and London: Routledge, pp. 207-222.

Rhedding-Jones, J. and Otterstad, A.M. (2010) Editorial. Reconceptualizing Educational Research Methodology. 1(1): 1-4. www.rerm.hio.no

Rossholt, N. (2009) The complexity of bodily events through an ethnographer's gaze: focusing on the youngest children in preschool. Contemporary Issues in Early Childhood, 10(1): 55-64.

Sandvik, N. (2010) The art of/in educational research: assemblages at work. Reconceptualizing Educational Research Methodology, 1(1): 29-40.

Spivak, C. G. (1999) A Critique of Postcolonial Reason: Toward a history of the vanishing present. Cambridge Massachusetts and London UK: Harvard University Press.

Yelland, N. (ed.) (2005) Critical Issues in Early Childhood Education. Berkshire and New York: Open University Press. 